\title{
Character Education Concepts and Values in The Teaching of Gratitude (A Critical Analysis of Major Qur'anic Exegesis Texts)
}

doi.org/10.18196/afkaruna.v17i2.13399

\section{Akif Khilmiyah' Wahid Setiawan ${ }^{\mathbf{2}}$}

Universitas Muhammadiyah Yogyakarta

akif.khilmiyah@umy.ac.id

\begin{abstract}
This paper aimed to explore and find the concept and content of character values of being grateful. This research was library research using qualitative data types. The primary sources were Tafsr al-Qurān al-'Azim, Tafsr al-Fakhri ar-Rāzi, Tafsr al-Maraghi, at-Tafsir al-Munir, Tafsr al-Karim ar-Rahmān fā Tafsir Kalām, and Tafsir al-Azhar. At the same time, secondary sources were books or journals related to the concept of gratitude and the value of character education. Data from sources were collected using documentation, then analyzed using subjective thematic interpretation methods and objective hermeneutics. The results showed that the concept of character education in the teaching of gratitude in QS. Ibrahim (14): 7 is both targib (motivation) and tarhib (threat). This concept will make humans remain in the circle of goodness, who is always patient and grateful to Allah SWT. There are nine values of character education in the teaching of gratitude: trustworthiness, qanāah, creativity, hard work, trustworthiness, optimism, caring for others, tawaduk, and istiqamah. These values will be attached to someone who makes gratitude a habit that can be both a motivation and a threat (targib wa tarhib). These nine character values will have implications for increasing devotion to Allah SWT and increasing compassion for fellow creatures.

Keywords: Concept, Value of Character Education, Gratitude
\end{abstract}




\section{ABSTRAK}

Tulisan ini bertujuan untuk menggali dan menemukan konsep dan kandungan nilai-nilai karakter dalam ajaran kebersyukuran. Jenis penelitian ini adalah penelitian kepustakaan dengan menggunakan jenis data kualitatif. Sumber primer yang digunakan adalah kitab Tafsir al-Qurān al-'Alim, Tafsir al-Fakhri ar-Rāzi, Tafsir al-Maraghi, at-Tafsir al-Munir, Tafsir al-Karim ar-Rahmān fi Tafsir Kalām al-Mannān, dan Tafsir al-Azhar. Sedangkan sumber sekunder berupa buku-buku atau jurnal yang berhubungan dengan konsep kebersyukuran dan nilai pendidikan karakter. Data dari sumber dikumpulkan menggunakan teknik dokumentasi, kemudian dianalisis menggunakan metode tafsir tematik subjektif, dan hermenutik obyektif. Hasil penelitian menemukan bahwa konsep pendidikan karakter dalam ajaran kebersyukuran Q.S. Ibrahim (14): 7 adalah targib (motivasi) sekaligus tarhib (ancaman). Konsep tersebut akan menjadikan manusia tetap berada dalam lingkaran kebaikan, yang selalu bersabar dan bersyukur kepada Allah swt. Teradapat sembilan nilai-nilai pendidikan karakter dalam ajaran kebersyukuran yaitu: amanah, qanā'ah, kreatif, kerja keras, tawakal, optimis, peduli terhadap sesama, tawaduk, dan istiqamah. Nilai-nilai tersebut akan melekat pada seseorang yang menjadikan syukur sebagai kebiasaan yang dapat menjadi motivasi dan juga ancaman (targib wa tarhib). Sembilan nilai karakter ini akan berimplikasi pada peningkatan ketaqwaan kepada Allah SWT dan peningkatan kasih sayang kepada sesama makhluk.

Keywords: Konsep; Nilai Pendidikan Karakter; Kebersyukuran.

\section{INTRODUCTION}

Humans are created in perfect conditions to support daily activities.' Perfection is certainly not separated from the many blessings God has given to humans. Therefore, people should be grateful for these blessings, as stated in QS. Ibrahim (14): 34. "And He gave you from all you asked of Him. And if you should count the favor of Allah, you could not enumerate them. Indeed, mankind is most unjust and ungrateful."

The verse above explains that Allah's blessings to His servants are uncountable. According to Imam as-Sa'di, a person's level of gratitude must be directly proportional to the blessings obtained ${ }^{2}$. A person must always be grateful since God always bless us all. Gratitude by humans, even though it is an obligation from Allah SWT, will bring benefits for 
humans. This has been revealed in the Qur'an and reinforced by various evidence that the gratitude expressed by a person will produce the hormone of happiness in him ${ }^{3}$ and develop his mental health ${ }^{4}$. That way, he will avoid stress and depression because of the problems he is facing. ${ }^{5}$ Gratitude is closely related to the level of welfare of one's life because gratitude is a form of expression of the happiness of one's soul. ${ }^{6}$

This well-being includes psychological well-being, emotional well-being, and subjective well-being ${ }^{7}$. By being grateful, someone will be greatly helped to enjoy his life, as well as when he gets a special gift from someone he loves so that he has the opportunity to reach the greatest possibilities in his life ${ }^{8}$. Gratitude can be realized by always remembering Allah SWT through heart, tongue, and limbs. Remembering with the heart means contemplating the signs of Allah's power, verbally by always remembering His name, and through the limbs by doing good deeds. ${ }^{9}$ However, in reality, many people still do not understand gratitude, ${ }^{10}$ and it affects the way to realize gratitude. Some people realize their gratitude by saying "Alhamdulillah," but after that, they complain about the problems they are facing.

Some people think that gratitude is only done when they get sustenance in the form of money, so gratitude is realized by having a meal with friends or is often called a thanksgiving event. ${ }^{11}$ Even some people interpret gratitude as giving alms to the earth because of abundant harvest, ${ }^{12}$ to avoid mountain disaster, ${ }^{13}$ or getting rid of misfortunes (something that may lead to disaster). ${ }^{14}$ Of course, such an expression of gratitude has no guidance in Islamic law and is actually closer to shirk, 15 and does not bring one's self to the happiness and glory of life.

The verse explains that if a servant is grateful for the blessings that Allah SWT has given, by actualizing himself to unite and obey Allah, then Allah will add favors to him. ${ }^{16}$ These additions can be in the form of rewards for kindness, additional favors, happiness in the afterlife, and unlimited enjoyment, as gratitude also means unlimited ${ }^{17}$ In addition, the verse also contains educational concepts and values from God in instilling an attitude of gratitude in His servants. These values can be used to 
measure a person's level of success in gratitude. ${ }^{18}$ However, these concepts and values are still abstract. Therefore, it is necessary to have an interpretation of the verse in order to get a clear picture of the concept of character education and the values of character education in the holy verses.

The interpretation of the Qur'an, especially in the concept of gratitude contained in QS. Ibrahim (14): 7 can be seen in the mu'tabar commentary books. Also, books of tafsir have a fairly complex discussion of the verse of gratitude in both bi al-ma'sur and bi ar-Ra'yi. Moreover, by reviewing classical and modern commentary books, more comprehensive results will be found in understanding the verse of gratitude.

Character education is a broad term because it involves many sub-components that contribute to the implementation of character education itself. According to Thomas Lickona, ${ }^{19}$ character education is a deliberate effort to develop good character, both for individuals and society. ${ }^{20}$ In line with this understanding, Mike Frye et al. define character education as an effort that is made intentionally to help someone understand, care about something, and act in accordance with ethical values. ${ }^{21}$ Thus, in character education, three components must be processed: mind, taste, and body. According to a study, ${ }^{22}$ character education occupies a higher position than moral education. Character education does not only teach about right and wrong, ${ }^{23}$ but rather on inculcating good habits in individuals so that they are able to master the cognitive, affective, and psychomotor or behavioral domains: understand the good and the bad, be able to feel the value of goodness, and can apply it in everyday life.

In Islam, gratitude is often referred to as gratitude. Imam Ibn Qoyyim defines gratitude as an act of praising or thanking for the blessings that Allah SWT has given. ${ }^{24}$ According to Asy-Syibly, gratitude means an awareness of someone towards the creator who gives blessings, saying thank you regardless of the form of the favor itself. Yunahar Ilyas also expressed a similar understanding that gratitude is praising the giver of favors for good deeds. ${ }^{25}$ Based on some of the definitions above, it can be defined that gratitude is an expression of gratitude from the recipient of 
the favor to the giver of the favor, starting from the heart, then verbally, and proven by real actions

The reason for choosing Tafsr al-Qurān al-'Azim, Tafsr al-Fakhri ar-Rāzi, Tafsir al-Maraghi, at-Tafsir al-Munir, Tafsir al-Karim ar-Rahmān fā Tafsir Kalām, and Tafsir al-Azhar as references for character education as references in this study is because the six interpretations explain character education comprehensively, which includes knowledge of goodness, feeling the existence of goodness, and good behavior. Meanwhile, the concept of character building was proposed by Thomas Lickona.

Based on the description above, the research focused on examining more deeply the concept of character education in the teachings of gratitude in QS. Ibrahim (14): 7, along with the value of character education in the teachings of gratitude. Consequently, this study aimed to find the concept of character education and the values of character education contained in the QS. Ibrahim (14): 7, which is helpful for strengthening the character of students.

\section{Research Methods}

This study was library research using qualitative data. The primary sources were from Tafsr al-Qurān al-'Azim, Tafsr al-Fakhri ar-Rāzi, Tafsr al-Maraghi, at-Tafsir al-Munir, Tafsr al-Karim ar-Rahmān fā Tafsir Kalām, and Tafsir al-Azhar. At the same time, secondary sources were from books or journals related to the concepts and values of character education and morality. Data from sources were collected using documentation technique, then analyzed using subjective thematic interpretation method.

Next, the collected data were analyzed using descriptive analysis methods. ${ }^{26}$ This analysis consisted of data collection, data classification, analysis, and identification through subjective thematic interpretation. Analysis of thematic interpretation used the interpretation method of Mustafa Muslim, in his book entitled Mabāhis fi at-Tafsir al-Maudū'i. There are seven steps ${ }^{27}$ taken in analyzing this thematic interpretation: (1) choosing the title of the discussion to be studied in the Qur'an thematically. (2) Searching for and collecting verses of the Qur'an related 
to the subject matter (munasabah verse). (3) Arrange and sort the verses of the Qur'an related to the subject matter. (4) Perfectly study these verses by looking at the interpretations of the scholars. (5) Drafting a systematic discussion of themes and main material in a framework of thought. (6) Completing the discussion with the traditions of the Prophet. (7) Conducting a thorough analysis of these verses, then correlating them with existing research related to the theme or object of discussion in the interpretation.

\section{Discussion}

The research on the concept and value of character education in the teaching of gratitude refers to several well-known interpretation books, both classical commentaries and modern commentaries.

\section{Gratitude in Tafsir al-Quran al-'Azim}

Tafsir al-Qurān al-'Azim or also called Tafsir Ibn Kasur, the author is named Abu al-Fidā' Imāduddin Ism'āil Ibn 'Umar Ibn Katsir al-Quraish. In his interpretation, Ibn Kasur explains that the meaning of the sentence "wa idz taazdana rabbuka layab 'asanna 'alaihim ila yaumil qiyamah...," which means "and remember when your Lord made known His promise to the Children of Israel, that indeed, He will send people who will inflict the worst punishment on the Jews until the Day of Resurrection."

According to Ibn Kasur, the arrangement of these sentences can also be interpreted as Allah's oath to the Children of Israel. Furthermore, in interpreting the next word, "lain syakartum laazidannakum." Ibn Kasur also explains that if they (the Children of Israel) are grateful for the blessings that Allah SWT has given, then surely Allah will add favors to them in the form of goodness. But if what happens is the opposite, "wa lain kafartum" and if they (the Children of Israel) disobey the favors that have been given by Allah, either by covering them up or not being grateful for these favors, they do not want to obey Allah's orders through His messenger, and act arrogantly with these favors, then Allah will inflict punishment on him "inna 'adzabi lasyadiid", and in fact, Allah's punishment is very severe. So the torment is only given specifically to those who do kufr favors. ${ }^{28}$ 
From the Tafsir of Ibn Kasur above, every blessing must be followed with gratitude, even for small and not useful favors, and it will trigger the increase in pleasure. In addition, the perpetrators of kufr favors will receive punishment from Allah SWT, and the punishment is reserved for the perpetrators, not for other people. Although Ibn Kasur did not explain how to manifest gratitude in detail, through his interpretation, a lesson can be drawn that gratitude cannot be separated from three things: the heart, tongue, and limbs. Be careful with the qanā'ah order for something that is accepted. Oral with thanks, and praise the greatness of Allah SWT. Members of the body with an attitude ready to carry out all the commands of Allah and stay away from all that He forbids, obey without expression but and obey unconditionally.

\section{Gratitude in at-Tafsir al-Kabir wa Mafatih al-Gaib}

The Book of Tafsir ar-Rāzi or often known as the Kitab at-Tafsr al-Kabir wa Mafātih al-Gaib is a book of interpretation written by Muhammad Ibn 'Umar Ibn Hasan al-Tamimial-Bakri al-Tibristāni ar-Rāzi..29 The book is in bi al-ra'y and semi bi ma'sūr ${ }^{30}$ with the ijmāli method and bi 'ilmi style. According to ar-Rāzi, the verse contains three discussions: First, someone preoccupied with being grateful. Second, the essence of gratitude. Third, additional favors.

The first discussion is that for someone busy with gratitude, then Allah will give him additional blessings as the oath and promise of Allah SWT. The second discussion is about the nature of gratitude. The meaning of gratitude, according to ar-Rāzij ${ }^{31}$, has the meaning: An expression of acknowledgment of the favors of Allah SWT, accompanied by glorifying Him and fulfilling oneself in this way. The third discussion, obtaining two additional pleasures, spiritual and physical pleasures. Spiritual favors are obtained because gratitude will present parts of the blessings of Allah SWT, as well as various virtues and His glory.

For example, when someone often does good deeds to others, he will love the good habit, and the good habit becomes the character. Then the good he does will be a reinforcement of love for Allah SWT. There is no doubt that the source of happiness and the branches of all goodness is 
the love of Allah because of knowing Him deeply. At the same time, the additional pleasure for the body is a person's firm and consistent attitude in doing good. In other words, gratitude occupies a high position to achieve happiness in this world and the hereafter. The meaning of kufr in QS. Ibrahim (14): 7 is kufr favors, instead of in the sense of apostasy from Islam. According to ar-Rāzi, kufr favors will not happen except to stupid people who do not know the favors of Allah SWT. Ar-Rāzi also argued that ignorance of Allah includes sanctions and punishments. ${ }^{32}$

Based on ar-Rāzi's interpretation, it can be concluded that gratitude must begin with acknowledgment, both in the heart and verbally, to glorify Allah SWT. Then expressed by good deeds that can draw closer to Allah SWT and know Him deeply. Such gratitude will bring additional blessings from Allah SWT in the form of physical and spiritual favors, worldly and hereafter blessings. While kufr favors are only for people who do not want to know Allah, and they are classified as getting punishment for those who do it in the world.

\section{Gratitude in Tafsir al-Karim ar-Rahmān fi Tafsir Kalam al-Mannan}

The book of Tafsir al-Karim ar-Rahmān fi Tafsr Kalām al-Mannān or often referred to as the book of Tafsir as-Sa'di is a book of interpretation by Abdurrahman Ibn Nasiru as-Sa'di. In interpreting QS. Ibrahim (14): 7, as-Sa'di explained about remembrance first, that remembering Allah must be with two things, the heart and the tongue. Both are a unity that cannot be separated, both in remembrance and gratitude. When remembrance and gratitude are depicted as body, then remembrance is the head, and gratitude is the limb. In this case, as-Sa'di rests on the hadith of the Prophet as follows: "Whoever remembers Me in himself I will remember him in Myself, if he remembers Me in a group of people I will remember him in a group that is better and better than him" (HR. Muslim, No. 4832).

Then as-Sa'di explained about gratitude. As for the gratitude referred to by as-Sa'di is to use three components at once, the heart, mouth, and limbs. Using the heart can be in the form of testimony and acknowledgment of the blessings that have been given by Allah SWT. 
Using the tongue can be in the form of wetting the tongue with dhikr and praising the greatness of Allah SWT. The definition of gratitude, according to as-Sa'di is the recognition of the heart for the favors of Allah, praising Allah for His favors, and using it for things that are pleasing to Allah, while kufr is the opposite. The meaning of kufr is an unwillingness to be grateful for the blessings that have been given by Allah SWT and not use them for good things. According to ${ }^{33}$ that kufr has many kinds and types, and kufr in verse has a general meaning, which is kufr favors. Meanwhile, kufr favors are still classified as disobedience and do not exclude the perpetrator from Islam.

From the interpretation of as-Sa'di above, it can be concluded that the form of gratitude must use three components at once: the heart, the tongue, and the good deeds. Being grateful with the heart is by acknowledging and believing that the favors are from Allah SWT. Gratitude verbally in the form of a habit of remembrance praising Allah SWT. Gratitude with actions in the form of carrying out Allah's commands and staying away from His prohibitions. In contrast, kufr favor is classified as a heinous act and displeased Allah SWT because it includes immoral behavior towards Allah SWT.

\section{Gratitude in at-Tafsir al-Munir fi al-'Aqidah wa Asy-Syari'ah wa Al-Manhaj}

The book at-Tafsir al-Munir fi al-'Aqidah wa ash-Syari'ah wa al-Manhaj or known as the book at-Tafsir al-Munir is a book of tafsr by Wahbah az-Zuhaili. This tafsir has a mixed tahlili method, Tafsr bi al-ma'sūr, and Tafsr bi ar-Ra'yi. According to az-Zuhaili, the verse warns the Children of Israel to remember something that Allah SWT has promised. When Allah announces that He will increase favors to anyone grateful for the favors that have been given to him, in this regard, az-Zuhaili quotes a hadith from Anas, as follows: "Whoever is inspired to be grateful, it is not hindered from getting additional."

At the end of the interpretation, ${ }^{34}$ it provides a summary of the wisdom contained in verse, including: (1). Humans should take lessons from events that happened to the previous people and get used to remembering the favors of Allah. This is a combination of targib and 
tarhib, promises and threats. Targib lies in the words of Moses to his people or to others to always remember the favors that Allah has given. In comparison, tarhib in the form of lafadl reminds people of the rewards and punishments from Allah against those who deny His favors or kufr favor. (2) The content of advice and warning is contained in the lafadl, which shows people who are able to be patient and grateful. Indeed, being grateful for the favors will increase the favors, and kufr for the favors will reduce the favors or even erase the favors. (3) The benefits and harms of gratitude will return to those who practice gratitude or do not do gratitude. Allah, the Most Holy, and Exalted does not benefit or harm from the gratitude of His servants.

Based on the interpretation of az-Zuhaili above, it can be concluded that gratitude is remembering and knowing Allah SWT by heart, verbal, and knowing in every action. With such an expression of gratitude, Allah will increase the blessings in this world and the hereafter. While kufr favors are for people who do not know Allah (jahil murakab), and that will bring the punishment of Allah SWT. In his interpretation, az-Zuhaili also explained that the verse contains the concept of planting character from Allah SWT. The concept is in the form of targib (motivation) and tarhib (threat) methods. Motivation to always do good, and threats not to do bad deeds.

\section{Gratitude in Tafsir al-Maragi}

The author of the book of Tafsir al-Marāgi has the full name of Ahmad Mustafa Ibn Mustafa Ibn Muhammad Ibn 'Abd al-Mun'im al-Qadi al-Marāgi. The interpretation is classified in the form of tafsir bi al-ra'yi. ${ }^{35}$ According to al-Marāg, in brief, the verse can be understood that whoever is grateful to Allah for the sustenance that has been bestowed upon him, then Allah will make the path of sustenance clear for him. Whoever is grateful to Allah for the health benefits he feels, Allah will prolong his health. Whoever is grateful by obeying orders and avoiding all things that are forbidden by Allah, then He will instill obedience in the heart. 
But if they (the Children of Israel) disbelieve in the blessings that Allah has given, do not want to enforce their obligations as servants, use the favors for things that are hated or even forbidden by Allah, then the punishment will befall them. al-Marāgi also explained that the punishment inflicted on the kufr is not only limited to the hereafter but also in this world. ${ }^{36}$ The punishment in the world is the loss of sustenance (favors) that should be obtained in the world. Whereas in the hereafter, there will be torments that humans will not be able to bear. In this case, al-Marāg rests on the following hadith of the Prophet: "Indeed a servant is truly deprived of sustenance because of the sin he has committed." (HR. Ahmad, No. 21379)

Based on the interpretation of al-Marāgi above, the reward for the grateful person depends on his intention. Grateful for being healthy, Allah will maintain the healthy favors. Grateful for the sustenance, the blessings of sustenance will be added, and so on. Al-Marāg did not explain how to manifest true gratitude in detail, but through his interpretation above, gratitude starts from the heart and goes up to the mouth, expressed by actions, and these actions will bring recompense or reward.

\section{Gratitude in Tafsir al-Azhar}

Tafsr al-Azhar is a modern interpretation ${ }^{37}$ by Haji Abdul Malik Karim Amrullah (Buya Hamka) while in prison. ${ }^{38}$ In his book, Hamka includes several isrāiliyyah stories, with the aim of only being a complementary explanation. However, the story has been selected by Hamka and does not conflict with Islamic law. ${ }^{39}$

As for Hamka's tafsir of QS. Ibrahim (14): 7 is to be grateful for all the blessings that Allah has given by giving thanks. Speech is not just a word with the mouth but must be proven by actions. Therefore, Hamka is of the opinion that being grateful must be followed by continuous effort, constantly striving to find a way out of the problems at hand. Do not easily complain about the small problems that come your way. Don't complain about the lack of food supplies. Don't complain if you can't reach your dreams. However, we still must be grateful for what we have, then surely Allah will sustain us with His favors. 
To clarify his tafsir, Hamka cites the following hadith: "Indeed, a servant is truly deprived of sustenance because of the sin he has committed" (HR. Ahmad, No. 21379). Even though a person looks rich by birth with a myriad of assets he already has, if it is not halal, then his soul will always feel lonely, empty, always feel poor and lacking compared to others due to being ungrateful. ${ }^{40}$ After analyzing each of the commentary books as the references in this study, it can be seen very clearly that all commentators agree that the expression of gratitude cannot be separated from three things, first with conscience, which is to believe that all blessings come from Allah SWT since human efforts without God's intervention will be in vain. Second, verbally, by always remembering Allah SWT, praising Him for His majesty, and thanking Him. Third, we should manifest our gratitude with limbs or deeds ordered by Allah SWT, for example, doing charity with the sole intention of seeking the pleasure of Allah SWT, trying earnestly without giving up, or complaining. Such gratitude will lead a person to the happiness and glory of life, as well as the imprinting of character values in a person, as will be explained in the following discussion.

\section{The Reasons for The Revelation of The Verse about Gratitude}

In the book al-Mu'jam al-Mufahras li Alfādi al-Qur'ān al-Karim, there are 75 mentions of the word gratitude in the Qur'an (Baqi, 1364: 385-386). However, in this discussion, only a few will be presented, including QS an-Nahl (16): 78, QS al-Mu'minun (23): 78, QS. As-Sajdah (32): 9, Q.S. al-Mulk (67): 23.

The verses above explain gratitude, more precisely about how few people are able to be grateful for the blessings given by Allah SWT. Humans have been given by God great potentials in the form of hearing, sight, and conscience. With this potential, humans can think and acquire knowledge because it cannot be obtained except with one of these senses. But in reality, there are still a lot of people who are not grateful. This is a statement at the end of the verse, lafadl qalilan mā tasykuruna. Gratitude here is interpreted by using these potentials for things that can draw closer to Allah SWT or reach His pleasure. ${ }^{41}$ 
In the book al-Mu'jam al-Mufahras li Alfādi al-Qurān al-Karim, there are 75 mentions of the word gratitude in the Qur'an (Baqi, 1364: 385-386). However, in this discussion, only a few will be presented, including QS an-Nahl (16): 78, QS al-Mu'minun (23): 78, QS. As-Sajdah (32): 9, Q.S. al-Mulk (67): 23.

The verses above explain gratitude, more precisely about how few people are able to be grateful for the blessings given by Allah SWT. Humans have been given by God great potentials in the form of hearing, sight, and conscience. With this potential, humans can think and acquire knowledge because it cannot be obtained except with one of these senses. But in reality, there are still a lot of people who are not grateful. This is a statement at the end of the verse, lafadl qalilan mā tasykuruna. Gratitude here is interpreted by using these potentials for things that can draw closer to Allah SWT or reach His pleasure. ${ }^{41}$

Later described in QS al-Baqarah (2): 152, Allah SWT gives each portion of remembrance and gratitude and prioritizes remembrance over gratitude. According to a study, ${ }^{42}$ remembrance is the essence of gratitude. As a body, remembrance is the head, while gratitude is the body. Therefore, Allah placed the command of remembrance at the beginning with a specific command, then followed by thanksgiving with a general command. As-Sa'di also argues that gratitude should be done with the heart, mouth, and limbs. Then QS. Lukman (31): 12, the verse tells the story of Luqman, who received a gift from God in the form of wisdom. According to ar-Razi, wisdom is referred to as taufik in knowledge. ${ }^{43}$ If a person has learned knowledge, but he does not know the benefits of the knowledge he has learned, then he cannot be called getting wisdom. The verse stated mustaqbal lafaz, which means actions for the future.

According to ar-Rāzi, this is a sign that gratitude must be repeated. In contrast, kufr is mentioned with fi'il mādi, which means enough and should not be repeated. ar-Rāzi also explains that the benefits of gratitude will only return to the doer. And vice versa, that the harm of kufr will also return to the perpetrator. Meanwhile, Allah, the Richest, the Most Praised, is not affected in the slightest by the consequences of 
gratitude or kufr of a servant. Then QS an-Naml (27): 40, the verse tells of Prophet Solomon when he was about to move the throne of Queen Bilqis in front of him. Allah SWT made it easy for him to do this. So when it happened, Solomon realized that it was impossible. ${ }^{44}$ The point is that kufr does not need to be repeated and is fulfilled immediately. Therefore, an educational concept is needed in instilling the habit of gratitude so that a grateful personality can be formed in a person. The concept of education will be explained in the following discussion.

\section{Values of Character Education in Gratefulness}

The Qur'an was revealed as a guide for all humans. ${ }^{45}$ Accordingly, QS. Ibrahim (14): 7 shows how to live a happy life. In the content of the verse, God made a covenant with humans. According to its tafsir, humans here mean the Children of Israel. Whoever is grateful for the blessings that Allah has given, then He will increase these blessings. On the other hand, whoever denies His favor, He has prepared punishment for them. Therefore, the verse contains the concept of targib (motivation) as well as tarhib (threat).

Targib (Motivation) has the root of yeastba-yargabu, which means liking or loving. ${ }^{46}$ Then the isim masdar is followed with wazan taf'il, so that it becomes targib which means encouragement or motivation. Targib can also be interpreted with the promise of happiness, pleasure, enjoyment accompanied by seduction or persuasion. In terminology, Syamsul Ulum provides an understanding of target as a means of encouraging preventive and repressive education, boosting enthusiasm, and increasing one's learning motivation to become better.47 Related to QS. Ibrahim (14): 7, targib means motivation so that humans are always grateful for the blessings of Allah SWT.

Tarhib (Threat) comes from the word rahaba-yarhabu, which means fear. Then the masdar follows wazan tafil, which has the meaning of punishment, scaring, threatening by giving sanctions, thereby causing fear in the heart to commit violations. ${ }^{48}$ In the terminology of the Qur-an, it is also often referred to as iqāb, which means punishment. Terminologically, according to Arifin, punishment has the meaning of 
intentional suffering given by educators (whether teachers, parents, or others) after a violation, mistake, or crime has occurred. ${ }^{49}$ Related to QS. Ibrahim (14): 7, tarhib means a threat to anyone who dares to disobey or disbelieve in the blessings of Allah SWT.

These two methods, both targib and tarhib, are a unity that cannot be separated. If the two are separated, it will not give expected results. Islam uses this concept to always believe in Allah and His Messenger. So it can be ascertained that these two methods will make humans remain in the circle of goodness.

Thus, it can be concluded that in gratitude in QS. Ibrahim (14): 7 contains the concept of character education, targib (motivation) as well as tarhib (threat). The two concepts are inseparable units. Because both of them will keep humans in the circle of goodness, which is to always be patient and grateful to Allah SWT, in addition, the concept can also be used to instill character education values in humans. According to the Ministry of National Education, there are 18 points of character education values that must be instilled in each individual, as mentioned in the previous discussion ${ }^{50}$.

\section{Analysis of Character Education Values in Gratitude Teaching}

After reading from some of these commentaries and some opinions of the commentators on the content of character education values contained in QS. Ibrahim (14): 7, it was found that the teaching of gratitude contained the values of character education as follows:

\section{Amanah Character Value}

The value of amanah education is also reflected in QS. An-Naml (27): 19. According to as-Sa'di, Prophet Sulaiman asked Allah for guidance on how to be grateful, both for the blessings he had and the favors given to his parents, at the same time asking for instructions to do righteous deeds in accordance with what Allah SWT approves ${ }^{51}$. Based on this view, it can be understood that a person's form of gratitude can be in the form of good deeds according to the pleasure of Allah SWT. 
In addition, another verse gives a signal that gratitude trains an educated person to be amanah, in QS. Al-A'raf (7): 58 This verse explains the need to take advantage of God's grace in accordance with its functions and provisions. ${ }^{52}$ Likewise, QS ar-Rūm (30): 46 explains that the meaning of gratitude is to use God's gift in accordance with the purpose of giving it. The same verse is QS. Sabā' (34): 15, gratitude means using God's gifts according to His direction. Also supported by the verse QS al-Baqarah (2): 172, which explains that gratitude is using God's gift to do good deeds, deeds that are pleasing to God, in other words putting something in its place.

\section{Qonaah Character Value}

Linguistically, Qanā'ah comes from the root word qani'a-yaqna'u-qanā'tan, which means feeling satisfied, willing to share ${ }^{53}$ Qanā'ah contains five indicators: 1) accepting voluntarily towards something that exists. 2) ask Allah for a proper addition, followed by continuing to strive. 3) full of patience in accepting the decree of Allah SWT. 4) always put your trust in Allah SWT. 5) not interested in the glittering world that can make people lulled. ${ }^{54}$ From the five indicators above, it can be concluded that Qanā'ah is more dominant in belief or related to the heart.

The relationship between Qanā'ah and gratitude is that people who are always grateful for Allah's favors, whether these blessings are small or large, will feel enough with what is there, and his life is always filled with happiness. According to a study, ${ }^{55}$ something that is a little in the eyes of a grateful person will feel enough, while something that is a lot in the view of a person in disbelief will feel less. Several verses indicate that gratitude educates a person to be qanā'ah, the following verses: QS. An-Nisa' (4); 147, Q.S. al-A'rāf (7): 144, Q.S. Al-Isra' (17):17-18, Q.S. An-Naml (27): 19, Q.S. al-Fātir (35): 30, Q.S. at-Tagābun (64): 17, and Q.S. Al-Insan (76): 22. 3. 


\section{Creative Character Value}

Creative Including the greatest blessings from Allah are the pleasures of hearing, sight, and conscience or mind, as stated in QS. An-Nahl (16): 78, QS. Al-Mu'minūn (23): 78, QS. As-Sajdah (32): 9, QS. Al-Mulk (67): 23, as explained in the previous discussion. According to Wahbah az-Zuhaili, the three blessings (hearing, seeing, and conscience or reason) are the main instruments for a person to gain knowledge in order to know and get closer to Allah SWT. Without these three blessings, a person will not be able to receive knowledge or teach it to others..$^{56}$ Based on this view, it can be understood that when someone is grateful for the three blessings, using them according to their nature, the value of creativity will appear automatically. The value of creativity helps humans survive by managing the natural wealth already available.

God's gifts are in the form of an expanse of ocean with millions of contents contained therein (Surah Fatir (35): 12), fertile land with millions of crops (Surah al-'Araf (7): 58), mountains containing gold, diamonds, and gems, (Surat an-Nahl (16): 14), are all blessings for which His servants should be grateful. Gratitude for such things can be realized by making the best use of this gift without damaging the existing ecosystem. Therefore, humans are required to have high creativity in managing these natural resources in order to create innovations, such as creating eco-friendly boats and nets to catch fish, inventing tractors to manage the land, creating mining tools, and so on.

\section{Hardworking Character Value}

Hard work is one of God's commands to show gratitude to Him by working hard. This is as stated in QS. Saba' (34): 13. Ibn Kasir explains that the verse tells about the Prophet Dawud's question of how to give thanks to Allah and be grateful for the blessings He has given. So Allah ordered Prophet Dawud and his followers to be grateful by working hard 57 .

Likewise, in the teachings contained in QS al-Ankabūt (29): 17, Ibn Kasir mentions that all sustenance comes from Allah SWT, so worship Him, and be grateful by seeking that sustenance ${ }^{58}$. According to Buya Hamka, gratitude must also be proven by hard work, continuously trying 
to overcome all the difficulties being faced, until they find a way out. Thus, one of the values of character education contained in the concept of gratitude is hard work.

\section{Tawakal Character Value}

Tawakal comes from Arabic, the root word wakala-yakilu, which means to surrender or entrust. Meanwhile, according to moral terminology, tawakal means freeing the conscience from all dependence on other than Allah while leaving all affairs only to Him. Realizing tawakal does not mean negating effort, but tawakal must still be started with effort and work hard. Trying with the limbs is a form of obedience to Allah SWT while trusting with the heart is a form of manifestation of faith in $\operatorname{Him}^{59}$.

The relationship between tawakal and gratitude is as illustrated in QS. An-Naml (27): 19, which describes the story of Prophet Sulaiman asking Allah for guidance on the right way to give thanks. Prophet Sulaiman left all affairs only to Allah SWT. Later described in QS al-Ankabut (29): 17 regarding sustenance, all sustenance comes from Allah SWT. So people should leave the matter of sustenance only to Him. Later described in QS al-Baqarah (2): 152 regarding remembrance and gratitude, Allah prioritizes the mention of remembrance of gratitude. This shows that gratitude must begin with the remembrance of Allah SWT.

\section{Optimistic Character Value}

The relationship of optimism with one's gratitude can be seen in QS. Ibrahim (14): 7. In that verse, Allah has promised His grateful servants additional favors. As for His servants who disbelieve in favors, Allah has provided such a painful punishment. So based on the explanation of this verse, it can be understood that in being grateful, a person is required to always be optimistic (full of good hope) about God's promises which are certain to be true. There should not be the slightest doubt in his heart. As explained in the quds hadith, Allah SWT said: From Abu Hurairah RA (narrated), the Prophet SAW said: Allah SWT said: "I am in the prejudice of My servant, and I am always with him when he remembers Me, if he 
remembers Me in himself, then I remember him in Myself, and if he remembers $\mathrm{Me}$ in an association, then I remember him in a better association than them" (Narrated by al-Bukhari, No. 6856). ${ }^{60}$

\section{ENDNOTES}

1 Kasur, I. (2009a). Tafsir al-Qurān al-'Alim (Jilid 4). Kairo: Dār Ibn al-Jauziy. 223

2 As-Sa'di, A. I. N. (2008a). Tafsir al-Karim ar-Rahmān fi Tafsir Kalām al-Mannān (Jilid 1). Mesir: Dār Ibnu al-Jauzy. 231

3 Lin, C.-C. (2019). Gratitude, Positive Emotion, and Satisfaction with Life: A Test Of Mediated Effect. Social Behavior and Personality: An International Journal, 47(4), 1-8.

4 Aziz, R., Wahyuni, E. N., \& Wargadinata, W. (2017). Kontribusi Bersyukur dan Memaafkan dalam Mengembangkan Kesehatan Mental di Tempat Kerja. INSAN Jurnal Psikologi Dan Kesehatan Mental, 2(1), 33ichard N. Frye, The Golden Age of Persia (USA: Harper \& Row Publishers Inc., 1975), 226.

5 Cunha, L. F., Pellanda, L. C., \& Reppold, C. T. (2019). Positive Psychology and Gratitude Interventions: A Randomized Clinical Trial. Frontiers in Psychology, 10

6 Bono, G., \& Sender, J. T. (2018). How Gratitude Connects Humans to the Best in Themselves and in Others.: Discovery Service for Perpustakaan Nasional Republik Indones. Routledge: Taylor \& Francis Group, 15, 224-237

7 Duprey, E. B., McKee, L. G., O’Neal, C. W., Algoe, S. B., \& Campos, B. (2020). Stressors, resources, and mental health among Latino adolescents: The role of gratitude. Journal of Applied Developmental Psychology, 70

8 Kardas, F., Cam, Z., Eskisu, M., \& Gelibolu, S. (2019). Gratitude, Hope, Optimism and Life Satisfaction as Predictors of Psychological Well-Being.

9 Eurasian Journal of Educational Research, 19(82), 1-20

Kasir.I. (2009b). Tafsir al-Qurān al-'Azim (Jilid 1). Kairo: Dār Ibn al-Jauziy. 219

10 Lam, K. K. L. (2021). The mediating effect of gratitude in the relationship between zest for life and depression. Personality and Individual Differences, 171.

11 Bauto, L. O. M., \& Nisma, W. O. (2019). Nilai Sosial Dan Tujuan Haroa Pada Acara Syukuran Masyarakat Muna di Desa Liabolano. Journal Publicuho, 2(3), 57 
12 Miftahudin, A. (2016). Penanaman Nilai Syukur Dalam Tradisi Sedekah Bumi di Dusun Kalitanjung Desa Tambaknegara Rawalo Banyumas (Institut Agama Islam Negri Purwokerto). 64

13 Putri, I. R., Faida, L. R. W., Fandeli, C., \& Purwanto, R. H. (2017). Tradisi Masyarakat Selo Dan Pariwisata di Taman Nasional Gunung Merbabu, Boyolali Jawa Tengah. SASDAYA: Gadjah Mada Journal of Humanities, 1(2), 199.

14 Ramadani, Y., \& Qommaneeci, A. (2018). Pengaruh Pelaksanaan Kenduri SKO (Pesta Panen) Terhadap Perekonomia Dan Kepercayaan Masyarakat Masyarakat Kerinci, Provinsi Jambi. Jurnal Antropologi: Isu-Isu Sosial Budaya, 20(1), 71.

15 Umar, A. (2017). Strategi Dakwah Kultural Muhammadiyah pada Ritual Adat Mappogau Hanua Masyarakat. Afkaruna, 13(2). 61

16 Az-Zuhaili, W. (2009a). At-Tafsir al-Munir fi Al-Aqidah wa Asy-Syari'ah wa Al-Manhaj (Jilid 7). Kairo: Dār al-Fikr 154

17 Al-Jauziyyah, I. Q. (2017). Tazkiyatun Nafs: Konsep Penyucian Jiwa Menurut Ulama Salafushshalih. Solo: Pustaka Arafah, 75

18 Morgan, B., Gulliford, L., \& Kristjánsson, K. (2017). A new approach to measuring moral virtues: The Multi-Component Gratitude Measure. Personality and Individual Differences, 107, 179-189.

19 Khilmiyah, A., \& Wiyono, G. (2021). Emotional and social intelligence assessment model for student character reinforcement. International Journal of Educational Management, 45

20 Yaumi, M. (2018). Pendidikan Karakter: Landasan, Pilar, dan Implementasi. Jakarta: Prenadamedia Group. 16

21 Frye, M., Lee, A. R., LeGette, H., Mitchell, M., Turner, G., \& Vincent, P. F. (2002). Character Education: Informational Handbook and Guide for Support and Implementation of the Student Citizen Act of 2001. In Thought (Vol. 12).170

22 Khilmiyah, A. (2013). Perbandingan Ketrampilan Intrapersonal dan Interpersonal Berbasis Pendidika Karakter Siswa Sekolah Dasar Negeri Kasihan Bantul. Afkaruna, 9(1), 50-64.

23 Khilmiyah, A., Wiyono, G., \& Suud, F. M. (2020). The principal's instructional leadership ability in strengthening the character of junior high school students of Muhammadiyah. Humanities and Social Sciences Reviews, 8(3).53

24 Al-Jauziyyah, I. Q. (2017). Tazkiyatun Nafs: Konsep Penyucian Jiwa Menurut Ulama Salafushshalih. Solo: Pustaka Arafah, 60

25 Ilyas, Y. (2016). Kuliah Akhlaq. Yogyakarta: LPPI. 12

26 Khilmiyah, A. (2016).Metode Penelitian Kualitatif. Yogyakarta: Samudra 
Biru. 139

27 Muslim, M. (2000). Mabāhis fi at-Tafsir al-Maudu'i. Damaskus: Dārul Qalam. 23

28 Kasir,I. (2009c). Tafsir al-Qurān al-'Azim (Jilid 2). Kairo: Dār Ibn al-Jauziy 224

29 Al-Qatān, M. (2017). Mabāhis Fi 'Ulūmi al-Qurān. Kairo: Dār al-'Ilmi wa al-imān. Al-Seheel, A. Y., \& Noor, N. M. (2016). Effects of an Islamic-Based Gratitude Strategy on Muslim Students' Level of Happiness. Mental Health, Religion \& Culture, 19(7), 686.

30 Ash-Shiddieqy, M. H. (2013). Sejarah dan Pengantar Ilmu Al-Qur'an dan Tafsir (Ketiga). Semarang: Pustaka Rizki Putra. 24

31 Fakhruddin, M. ar-R. (1981a). Tafsir al-Fakhri ar-Rāzi al-Masyhūr bi al-Tafsir al-Kabur wa Mafātih al-Gaib (Jilid 19). Kairo: Dār al-Fikr. 232

32 Fakhruddin, M.ar-R.(1981b). Tafsir al-Fakhri ar-Rāzi al-Masyhūr bi al-Tafsir al-Kabur wa Mafātih al-Gaib (Jilid 32). Kairo: Dār al-Fikr. 134

33 As-Sa'di, A. I. N. (2008a). Tafsir al-Karim ar-Rahmān fi Tafsir Kalām al-Mannān (Jilid 1). Mesir: Dār Ibnu al-Jauzy 69

34 Az-Zuhaili (2009c). At-Tafsir al-Munir fi Al-'Aqidah wa Asy-Syari'ah wa Al-Manhaj (Jilid 11). Kairo: Dār al-Fikr. 231

35 Baidan, N. (2011). Metode Penafsiran Al-Qur'an: Kajian Kritis terhadap Ayat-ayat yang Beredaksi Mirip. Yogyakarta: Pustaka Pelajar. 32

36 Al-Marāgi, A. M. (1974b). Tafsir al-Maragi (Jilid 19). Mesir: Mustafā al-Bābi al- Halabi. 127-131

37 Surahman, C. (2014). Pergeseran Pemikiran Tafsir Di Indonesia:Sebuah Kajian Bibliografis. Afkaruna, 10(2), 217-232

38 Rahmanto, M. (2018). Hamka dan Tafsir Harmonisasi Keislaman dan Keindonesiaan. Afkaruna, 14(1),133-145

39 39. Avivy, A. L. F., Dakir, J., \& Ibrahim, M. (2015). Isra'iliyyat in interpretive literature of Indonesia: A comparison between Tafsir Marah Labid and Tafsir al-Azhar. Mediterranean Journal of Social Sciences, 6(3), 401-407.

40 Hamka. (2015a). Tafsir al-Azhar (Jilid 5). Jakarta: Gema Insani. 89-90

41 Az-Zuhaili, W. (2009b). At-Tafsir al-Munir fi Al-'Aqidah wa Asy-Syari'ah wa Al-Manhaj (Jilid 7). Kairo: Dār al-Fikr36

42 As-Sa'di, A. I. N. (2008a). Tafsir al-Karim ar-Rahmān fi Tafsir Kalām al-Mannān (Jilid 1). Mesir: Dār Ibnu al-Jauzy 69

43 Fakhruddin. (1981b). Tafsir al-Fakhri ar-Rāzi al-Masyhūr bi al-Tafsir al-Kabur wa Mafātih al-Gaib (Jilid 32). Kairo: Dār al-Fikr. 146

44 al-Marāgi. (1974b). Tafsir al-Marāgi (Jilid 13). Mesir: Mustafā al-Bābi al-Halabi. 141-142 
45 Racmawan, H. (2013). Hermeneutika Alquran Kontekstual: Metode Menafsirkan Alquran Abdullah Saeed.Afkaruna, 9(2),148-161

46 Munawwir, A. W. (1997). Kamus Al-Munawwir: Arab-Indonesia Terlengkap.Surabaya: Penerbit Pustaka Progressif. 511

47 Anggraini, F. S. (2018). Targhib Wa Tarhib Perspektif Al-Quran. Inovatif: Jurnal Penelitian Pendidikan, Agama Dan Kebudayaan, 4(1), 141-165.

Munawwir, A. W. (1997). Kamus Al-Munawwir: Arab-Indonesia

48 Terlengkap.Surabaya: Penerbit Pustaka Progressif. 539

Anggraini, F. S. (2018). Targhib Wa Tarhib Perspektif Al-Quran. Inovatif:

49 Jurnal Penelitian Pendidikan, Agama Dan Kebudayaan, 4(1), 141-165.

50 As-Sa'di, A. I. N. (2008a). Tafsir al-Karim ar-Rahmān fi Tafsir Kalām

51 al-Mannān (Jilid 1). Mesir: Dār Ibnu al-Jauzy. 625

As-Sa'di, A. I. N. (2008b). Tafsial-Karim ar-Rahmān fi Tafsir Kalām al-Mannān (Jilid 2). Kairo: Dār Ibn al-Jauziy. 359

52 Munawwir, A. W. (1997). Kamus Al-Munawwir: Arab-Indonesia Terlengkap.Surabaya: Penerbit Pustaka Progressif. 1162

53 Hamka. (2018). Tasawuf Modern. Jakarta: Republika 267

54 Hamka. (2015b). Tafsir al-Azhar (Jilid 1). Jakarta: Gema Insani 90

55 Az-Zuhaili. (2009b). At-Tafsir al-Munir fi Al-'Aqidah wa Asy-Syari'ah wa Al-Manhaj (Jilid 15). Kairo: Dār al-Fikr. 36

56 Kasir.I. (2009d). Tafsir al-Qurān al-'Azim (Jilid 3). Kairo: Dār Ibn al-Jauziy. 265

57 Kasir.I . (2009c). Tafsir al-Qurān al-'Azim (Jilid 2). Kairo: Dār Ibn al-Jauziy 121

58 Al-Jauziyyah, I. Q. (2017). Tazkiyatun Nafs: Konsep Penyucian Jiwa Menurut Ulama Salafushshalih. Solo: Pustaka Arafah. 122

59 Al-Bukhārī, A. 'Abdillāh M. I. I. (2004). sahih al-Bukhārī. Bairūt: Dār al-Kutub al- 'Ilmiyyah 2694

60 Perpustakaan Nasional. (2007). Ensiklopedia Al-Qur'an: Kajian Kosakata. Jakarta:Lentera Hati. 939-940

61 Az-Zuhaili, W. (2009c). At-Tafsir al-Munir fi Al-Aqidah wa Asy-Syari'ah wa Al-Manhaj (Jilid 11). Kairo: Dār al-Fikr. 602

62 Ilyas, Y. (2016). Kuliah Akhlaq. Yogyakarta: LPPI. 123

63 Ilyas, Y. (2016). Kuliah Akhlaq. Yogyakarta: LPPI. 97

64 Al-Marāgi . (1974a). Tafsir al-Maragi (Jilid 15). Mesir: Mustafā al-Bābi al-Halabi. 27 


\section{REFERENCES}

Al-Bukhārī, A. 'Abdillāh M. I. I. (2004). sahīh al-Bukhārī. Bairūt: Dār al-Kutub al- 'Ilmiyyah.

Al-Jauziyyah, I. Q. (2017). Tazkiyatun Nafs: Konsep Penyucian Jiwa Menurut Ulama Salafushshalih. Solo: Pustaka Arafah.

Al-Marāgi, A. M. (1974c). Tafsir al-Maragi (Jilid 19). Mesir: Mustafā al-Bābi al- Halabi.

..... (1974a). Tafsir al-Maragi (Jilid 15). Mesir: Mustafā al-Bābi al-Halabi.

..... (1974b). Tafsir al-Marāgi (Jilid 13). Mesir: Mustafā al-Bāb al-Halabi.

Al-Qatān, M. (2017). Mabāhis Fi 'Ulūmi al-Qurān. Kairo: Dār al-'Ilmi wa al-mān. Al-Seheel, A. Y., \& Noor, N. M. (2016). Effects of an Islamic-Based Gratitude Strategy on Muslim Students' Level of Happiness. Mental Health, Religion \& Culture, 19(7), 686-703.https://doi.org/10.1080 $/ 13674676.2016 .1229287$

Anggraini, F. S. (2018). Targhib Wa Tarhib Perspektif Al-Quran. INOVATIF: Jurnal Penelitian Pendidikan, Agama Dan Kebudayaan, 4(1), 141-165. Retrieved from http://jurnal.staih.ac.id/index.php/inovatifarticle/view69

As-Sa'di, A. I. N. (2008a). Tafsir al-Karim ar-Rahmān fi Tafsìr Kalām al-Mannān (Jilid 1). Mesir: Dār Ibnu al-Jauzy

..... (2008b). Tafsir al-Karim ar-Rahmān fi Tafsir Kalām al-Mannān (Jilid 2). Kairo: Dār Ibn al-Jauziy.

Ash-Shiddieqy, M. H. (2013). Sejarah dan Pengantar Ilmu Al-Qur'an dan Tafsir (Ketiga). Semarang: PT. Pustaka Rizki Putra.

Avivy, A. L. F., Dakir, J., \& Ibrahim, M. (2015). Isra'iliyyat in interpretive literature of Indonesia: A comparison between Tafsir Marah Labid and Tafsir al-Azhar. Mediterranean Journal of Social Sciences, 6(3), 401-407. https://doi.org/10.5901/mjss.2015.v6n3s2p401

Az-Zuhaili, W. (2009a). At-Tafsir al-Munir fi Al-'Aqidah wa Asy-Syari'ah wa Al- Manhaj (Jilid 7). Kairo: Dār al-Fikr

..... (2009b). At-Tafsir al-Munir fi Al-Aqidah wa Asy-Syari'ah wa Al-Manhaj (Jilid 15). Kairo: Dār al-Fikr.

.... (2009c). At-Tafsir al-Munir fi Al-'Aqidah wa Asy-Syari'ah wa Al-Manhaj (Jilid 11). Kairo: Dār al-Fikr.

Aziz, R., Wahyuni, E. N., \& Wargadinata, W. (2017). Kontribusi Bersyukur dan Memaafkan dalam Mengembangkan Kesehatan Mental di Tempat Kerja. INSAN Jurnal Psikologi Dan Kesehatan Mental, 2(1), 33. https://doi.org/10.20473/jpkm.v2i12017.33-43 
Baidan, N. (2011). Metode Penafsiran Al-Qur'an: Kajian Kritis terhadap Ayat-ayat yang Beredaksi Mirip. Yogyakarta: Pustaka Pelajar.

Bauto, L. O. M., \& Nisma, W. O. (2019). Nilai Sosial Dan Tujuan Haroa Pada

Acara Syukuran Masyarakat Muna di Desa Liabolano. Journal Publicuho, 2(3), 57. https://doi.org/10.35817/jpu.v2i3.8278

Bono, G., \& Sender, J. T. (2018). How Gratitude Connects Humans to the Best in Themselves and in Others.: Discovery Service for Perpustakaan Nasional Republik Indones. Routledge: Taylor \& Francis Group, 15, 224-237. https://doi.org/10.1080/15427609.2018.1499350

Cunha, L. F., Pellanda, L. C., \& Reppold, C. T. (2019). Positive Psychology and Gratitude Interventions: A Randomized Clinical Trial. Frontiers in Psychology, 10. https://doi.org/10.3389/fpsyg.2019.00584

Duprey, E. B., McKee, L. G., O’Neal, C. W., Algoe, S. B., \& Campos, B. (2020). Stressors, resources, and mental health among Latino adolescents: The role of gratitude. Journal of Applied Developmental Psychology, 70. https://doi.org/10.1016/J.APPDEV.2020.101191

Fakhruddin, M. ar-R. (1981a). Tafsir al-Fakhri ar-Rāzi al-Masyhūr bi al-Tafsir al-Kabir wa Mafātih al-Gaib (Jilid 19). Kairo: Dār al-Fikr.

(1981b). Tafsir al-Fakhri ar-Rāzi al-Masyhūr bi al-Tafsir al-Kabir wa Mafātih al-Gaib (Jilid 32). Kairo: Dār al-Fikr.

Frye, M., Lee, A. R., LeGette, H., Mitchell, M., Turner, G., \& Vincent, P. F. (2002). Character Education: Informational Handbook and Guide for Support and Implementation of the Student Citizen Act of 2001. In Thought (Vol. 12). https://doi.org/10.5840/thought1937121109

Hamka. (2015a). Tafsir al-Azhar (Jilid 5). Jakarta: Gema Insani.

....... (2015b). Tafsir al-Azhar (Jilid 1). Jakarta: Gema Insani.

(2018). Tasawuf Modern. Jakarta: Republika

Yunahar. I. (2016). Kuliah Akhlaq. Yogyakarta: LPPI.

Kardas, F., Cam, Z., Eskisu, M., \& Gelibolu, S. (2019). Gratitude, Hope, Optimism and Life Satisfaction as Predictors of Psychological Well-Being. Eurasian Journal of Educational Research, 19(82), 1-20. https://doi.org/10.14689/ejer.2019.82.5

Kasir, I. (2009a). Tafsir al-Qurān al-'Azim (Jilid 4). Kairo: Dār Ibn al-Jauziy.

.... (2009b). Tafsir al-Qurān al-'Azim (Jilid 1). Kairo: Dār Ibn al-Jauziy.

..... (2009c). Tafsir al-Qurān al-'Azim (Jilid 2). Kairo: Dār Ibn al-Jauziy

..... (2009d). Tafsir al-Qurān al-'Azim (Jilid 3). Kairo: Dār Ibn al-Jauziy.

Khilmiyah, A. (2013). Perbandingan Ketrampilan Intrapersonal dan Interpersonal Berbasis Pendidika Karakter Siswa Sekolah Dasar Negeri 
Kasihan Bantul. Afkaruna, 9(1), 50-64.https://doi.org/10.18196 /aiijis.2013.0019.50-64

Khilmiyah, A. (2016). Metode Penelitian Kualitatif. Yogyakarta: Samudra Biru.

Khilmiyah, A., \& Wiyono, G. (2021). Emotional and social intelligence assessment model for student character reinforcement. International Journal of Educational Management,ahead-of-p(ahead-of-print).https:// doi.org/10.1108 https://doi.org/10.1108/IJEM-02-2020-0046

Khilmiyah, A., Wiyono, G., \& Suud, F. M. (2020). The principal's instructional leadership ability in strengthening the character of junior high school students of Muhammadiyah. Humanities and Social Sciences Reviews, 8(3). https://doi.org/10.18510/hssr.2020.8336

Lam, K. K. L. (2021). The mediating effect of gratitude in the relationship between zest for life and depression. Personality and Individual Differences, 171. https://doi.org/10.1016/J.PAID.2020.110476

Lin, C.-C. (2019). Gratitude, Positive Emotion, and Satisfaction with Life: A Test Of Mediated Effect. Social Behavior and Personality: An International Journal, 47(4), 1-8. https://doi.org/10.2224/sbp.4398

Miftahudin, A. (2016). Penanaman Nilai Syukur Dalam Tradisi Sedekah Bumi di Dusun Kalitanjung Desa Tambaknegara Rawalo Banyumas (Institut Agama Islam Negri Purwokerto). Retrieved from http:// repository.iainpurwokerto.ac.id/id/eprint/1484

Munawwir, A. W. (1997). Kamus Al-Munawwir: Arab-Indonesia Terlengkap.Surabaya: Penerbit Pustaka Progressif.

Morgan, B., Gulliford, L., \& Kristjánsson, K. (2017). A new approach to measuring moral virtues: The Multi-Component Gratitude Measure. Personality and Individual Differences, 107, 179-189. http://doi.org/10.1016/J.PAID.2016.11.044

Muslim, M. (2000). Mabāhis fi at-Tafsir al-Maudu'i. Damaskus: Dārul Qalam.

Perpustakaan Nasional. (2007). Ensiklopedia Al-Qur'an: Kajian Kosakata. Jakarta:Lentera Hati.15

Putri, I. R., Faida, L. R. W., Fandeli, C., \& Purwanto, R. H. (2017). Tradisi Masyarakat Selo Dan Pariwisata di Taman Nasional Gunung Merbabu, Boyolali Jawa Tengah. SASDAYA: Gadjah Mada Journal of Humanities, 1(2), 199. https://doi.org/10.22146/sasdayajournal.27782

Racmawan, H. (2013). Hermeneutika Alquran Kontekstual: Metode Menafsirkan Alquran Abdullah Saed. Afkaruna, 9(2),148 9(2),148-161. https://doi.org/10.18196/AIIJIS.2013. 
Rahmanto, M. (2018). Hamka dan Tafsir Harmonisasi Keislaman dan Keindonesiaan. Afkaruna, 14(1),133-145.https://doi.org/10.18196/aiijis .2018.0084.133-145

Ramadani, Y., \& Qommaneeci, A. (2018). Pengaruh Pelaksanaan Kenduri SKO (Pesta Panen) Terhadap Perekonomia Dan Kepercayaan Masyarakat Masyarakat Kerinci, Provinsi Jambi. Jurnal Antropologi: Isu-Isu Sosial Budaya, 20(1), 71. https://doi.org/10.25077/jantro.v20.n1.p71-83.2018

Surahman, C. (2014). Pergeseran Pemikiran Tafsir Di Indonesia:Sebuah Kajian Bibliografis. Afkaruna, 10(2), 217-232. https://doi.org/10.18196/AIIJIS. 2014

Umar, A. (2017). Strategi Dakwah Kultural Muhammadiyah pada Ritual Adat Mappogau Hanua Masyarakat. Afkaruna, 13(2). https://doi.org/10.18196/AIIJIS.2017.0073.204-239

Yaumi, M. (2018). Pendidikan Karakter: Landasan, Pilar, dan Implementasi. Jakarta: Prenadamedia Group. 